\title{
Officials and Officialdom
}

\author{
in the Middle of the 19th
}

and Beginning of the 20th Centuries

in the Social Structure of Tannu-Tuva

\author{
Salimaa S. Khovalyg* \\ Tuvan State University \\ 36 Lenina Str., Kyzyl, Tuva Republic, \\ 667000, Russia
}

Received 24.10.2016, received in revised form 14.12.2016, accepted 10.01.2017

The article describes a social structure of the traditional Tuvan society at the turn of the 19th and Beginning of the 20th Centuries. The author analyzes historical conditions for the formation of different classes and a special place occupied by officialdom. Officialdom of Tuva as an integral part of the traditional Tuvan society and the administrative system of the Qing Empire in the Central Asian region was formed and existed on the basis of a targeted government policy in the field of public administration. A study of formation and development of the officialdom as a whole is a new trend in historiography of Tuva. The research of the topic will provide an opportunity to fully explore the issue of formation and evolution of the managerial staff structure and can be very useful in solving problems of the management system at the present stage primarily in the national republics.

Keywords: ambyn-noyon, khoshun, ugerda, state apparatus, official, state management, tabunan (efu) - an imperial son in law, historiography, bugude-darga, class, social structure.

DOI: 10.17516/1997-1370-0017.

Research area: national history.

\section{Introduction}

Today, marking a 95-year anniversary of creation of the People's Republic of Tuva and summarizing theeconomicand socialdevelopment in Tuva, we inevitably turn back to the issue of quantitative and qualitative changes that have occurred during this significant period of time. A social sphere of the traditional Tuvan society has experienced the greatest transformation since the second half of the $19^{\text {th }}$ century. In a relatively short period of time there has been a change of several eras before the eyes of contemporaries, which was characterized by significant social changes that led to a completely different form of society and state. A purpose of the article is to examine officials and officialdom of TannuTuva as a social group that has occupied a special role in a social structure of the traditional Tuvan society since its formation till the present day. The scientific relevance of the research lies in the

(c) Siberian Federal University. All rights reserved

* Corresponding author E-mail address: salimaa@mail.ru 
lack of knowledge of the problem of formation and development of officialdom of Tuva in domestic and foreign historiography.

\section{Theoretical framework}

In historiography of Tuva, despite a huge number of works in history, ethnography, culture, socio-economic development, yet no attempt was made to comprehensively analyze the history of officialdom of Tuva, although historians have touched on some aspects from time to time. The relevant issues have been reflected in the research works that can be grouped chronologically into three stages: 1) from the second half of the $19^{\text {th }}$ till the first decade of the $20^{\text {th }}$ centuries; 2) from the 20 's till the beginning of the 90 's of the $20^{\text {th }}$ century; 3) from the early 90 's till the present time.

The first stage mainly involves the works of an ethnographic and journalistic nature and is set out in the writings of anthropologists, geographers and linguists. Travellers not so much studied history of the Tuvan people or the system of the administrative apparatus, the formation and development of the Tuvan officialdom, as described the administrative-territorial division, allocated tribal groups, studied traditions, customs, crafts, the anthropological look and kept record of the folklore (Adrianov, 1886: 25-26, Afrikanov, 1890: 34-59, Vatin-Bystrianskii, 1913, Vladimirtsov, 2002, Bichurin, 1834, Pozdneev, 1896, Potanin, 1883, Iakovlev, 1900, GrummGrzhimailo, 1926, 1930).

The second stage of historiography is inextricably linked with the adoption of a formational and class approach to history in the Soviet science. For the first time the Russian historians have developed periodization of the history of Tuva. Major attention was paid to the stages of establishment of power of the Manchu Qing Dynasty over the Tuvan people, formation of the Russian protectorate over Tuva, events of the Civil War and foreign intervention in the region, the history of formation and development of the Tuvan People's Republic (1921-1944), etc. However, questions of history of the Manchu domination and interaction between the Russian and the Tuvan peoples are often overly politicized. This mainly concerned the articles published in scientific journals. The main drawback was their journalistic character, the unreasoned use of such terms as "occupation", "colonization". Sometimes, even serious research works suffered from it (Leonov, 1923, Kaiskii, 1926, Natsov, 1927, Shostakovich, 1929).

Scientific understanding of the history of the Tuvan people begins with the works of Soviet historians (Kabo, 1934, Dulov, 1956, Potapov, 1969, Seifulin, 1968, Serdobov, 1971, Iezuitov, 1956, Aranchin, 1982). The apparent advantages of works of the Soviet scientists are: firstly, expansion of the research topic; secondly, inclusion of a wide range of sources into the study, including previously unused archival documents; thirdly, introduction of some features to the study of the Tuvan society in the early $20^{\text {th }}$ century, such as a system analysis, a formation approach, principles of historicism that helped to provide the first systematic description of the history of the Tuvan people. Here we should emphasize that the process of writing the history of Tuva itself was challenging not only in methodology. A source base created certain difficulties for the researchers. A new area of research was a study of the socio-economic and post-revolutionary history of Tuva. R.M. Kabo and V.I. Dulov were the first to study it. Later in the writings of the Soviet historians, the range socioeconomic problems has been expanded and a lot of attention has been paid to the history of party building and socio-political organizations of the Tuvan People's Republic, as well as the relationship with the Soviet Union. The 
historical and ethnographic research continued to develop, and the largest contribution to that was made by S.I. Vainshtein (Vainshtein, 1961). Ultimately, historiography of the history of the Tuvan people that was available at that time helped to carry out its generalization, the result of which was the two-volume "History of Tuva" written in the early 1960's, which covered the period from ancient times to 1961 (i.e. before the formation of the Tuvan Autonomous Republic). But still the problems of the formation and evolution of the officialdom, hierarchy and ranks of the Tuvan local government were covered insufficiently.

The third stage in the historiography of Tuva is marked by a change of ideological and methodological paradigms, which resulted in changes in the methods of research and historical description. At the same time, researchers have received access to previously closed sources allowing historians to reveal new aspects of the historical development of Tuva. The result was the emergence of works devoted to the cross-disciplinary issues of ethnopolitology, historical and legal anthropology, social history, etc. (Belov, 1997, 1999, Datsyshen, Ondar, 2003, Datsyshen, 2005, Moskalenko, 2004).

Scientists of the Institute of Humanitarian Studies of the Republic of Tyva have worked on systematization of materials taking into account the changed principles and methods of the research, extension of the source base and discovery of new facts from the history of Tuva. The result of their research was the new multivolume "History of Tuva".

Thus, despite some progress in the Tuvan and nationwide historiography, the questions of formation and evolution of the officialdom of Tuva at the turn of the $19^{\text {th }}$ - first half of the $20^{\text {th }}$ centuries have been studied occasionally, as auxiliary subjects.

\section{Statement of the problem}

The article reveals the issues of formation and establishment of the officialdom as a special professional and social group, within which the relations were based on the empire-wide formal-legal standards and their respective socio-psychological settings. In Tuva, there is a special administrative apparatus with a strong internal autonomy and a clear structure based on a rigid hierarchy of ranks, which is prone to local autonomy. The chronological scope of the study is limited by the turn of the $19^{\text {th }}$ - early $20^{\text {th }}$ century, when Tuva begins to be drawn into the orbit of the Russian statehood from the suburbs of the Manchurian Qing Empire. The lower limit is due to the functioning of the traditional officialdom of Tuva. It is from this time that the gradual transformation of society and the social image of a Tuvan official began. It is determined by the fact that by this time after the internal and external shocks a social composition has radically changed, as well as their system of ideological values and methods of recruitment of managerial staff of Tuva, which resulted in formation of foundations for the functioning of the state apparatus, which lasted until the collapse of the USSR.

\section{Methods}

The methodological basis of the study is composed of the principles of historicism, objectivism and a complex approach. They helped to examine the activities of the central and local governments starting with the first years of independent existence from the standpoint of dialectical development of events given the interconnection of this activity with the events that took place at that time not only in Tuva, but also in Russia and in neighbouring Mongolia and China. After examining the conditions of occurrence of the administrative apparatus in the era of the domination of the Manchu Qing Dynasty, the 
principle of historicism gives an opportunity to consider its dynamics in the interconnection and interdependence of the changing external conditions and to show a complete picture of the public administration system. The scientific objectivity was provided by the study of historical literature and an extensive documentary database of the research topic in all its diversity.

\section{Discussion}

At the turn of the $19^{\text {th }}-20^{\text {th }}$ centuries Tuva was part of the Manchu Qing Dynasty, the power of which was recognized by the Mongol princes at the end of the $17^{\text {th }}$ century, and the Tuvan tribes turned out to be in the Manchu-Mongolian dependence as a result of the fight against Dzungaria Manchu only by the middle of the $18^{\text {th }}$ century (Zhang, 1895: 70-73, 107, 404-405, 448-451). The Tuva society was distinguished by a strict hierarchy, where each person held a particular position corresponding to his status. At the turn of the $19^{\text {th }}-20^{\text {th }}$ centuries the social structure of Tuva was formed as a result of the aggressive policy of the Manchu and consisted of several social classes: the wealthy Tuvan, middle class and the poor. The first class, in turn, was divided into a princely estate, upper officialdom, clergy, Kara-bais who were engaged in trade, but not in service of the Mongolian-Manchurian administration. The second class mainly consisted of officials of middle and lower ranking and the Arats who had an independent economy. The third class included the permanently dependent Arats (Eshtenchi, Chalcha, Kholechik) and the poor (peonage). The upper class of the social hierarchy consisted of the Manchu nobility headed by an Emperor. The Manchu Emperor was a nominal owner of all the lands of Tuva, the Alban duty was annually paid in his name ${ }^{1}$, which was collected from each khoshun and personally delivered by an ambyn-noyon ${ }^{2}$ in Uliasutai ${ }^{3}$. They were followed by the Mongolian princes and rulers.
The Mongolian princes owned several Tuvan khoshuns $^{4}$ governed by their representatives called darga ${ }^{5}$. They performed administrative functions, collected duties in favor of their princes and controlled the activities of governors of the Tuvan sumons. "The Code of the Chinese Chamber of External Affairs" provided for significant rights and privileges for the Mongolian princes who had voluntarily sworn allegiance to the Manchu Emperor and had shown valor in the conquest of Dzungaria. The princes had the right to collect duties from their arats in strictly defined amounts (Lipovtsev, 1828: 132). In addition, the Beijing government set a particular allowance for them, which was paid from the Beijing treasury; introduced grants with ranks, medals and marks of distinction from the Bogdykhan. The Mongolian princes also enjoyed the tax and legal immunity. The Manchus formed a local military and civilian apparatus from their community. In the era of the Manchu domination the princely class added a new social group - the Tabunans. The Tabunans (efu) were the Mongolian princes who married the Manchu princesses and who had a preferential right to public office, and they were excused from paying all taxes and conscription. Thus, the Mongolian princes as a social support of the Manchus had the greatest rights and privileges. The Qing government encouraged in every way the desire of the Mongolian princes to take on the civil service. Gradually for the Mongolian (and the Tuvan) princes, a rank and a title have become equally important as the noble origins.

The Tuvan princes occupied the next class in the social hierarchy. V.I. Dulov thought that the princely estate in the Tuvan society was based on the institution of the clan commonwealth (zaisanstvo) developed back in the $17^{\text {th }}$ century (Dulov, 1956: 182-184). The Tuvan aristocracy included not only former zaisans ${ }^{6}$ who received new titles and positions: bugude-darga (ambynnoyon $)^{7}$, ugerda ${ }^{8}$, but also the Tuvan clergy. ${ }^{9}$ The 
highest official position was kamby-lama who performed the functions of the monastery abbot (Mongush, 2001: 70). Once the former rulers of clans, as well as the Mongolian princes, started to serve the Manchus, they were awarded new titles and ranks, which became the support for their social status. Together with the position and the title the Tuvan princes became the owners of all the rights and privileges that the southern neighbours had. The power was the main source of domination and enrichment in the Tuvan society.

The middle class of the traditional Tuvan society included minor officials holding the following positions in the khoshun administration: head of the administrative office - chagyrykchy; head of the sumon - changy, head of the arban desyatnik; special cases officer - chalan, assistant of changy - khundu, chief tax collector - boshka, secretary - bizheechi (Khovalyg, 2010: 97109). All the officials, except a tusalakchy, were appointed by the rules of the khoshuns. To appoint a tusalakchy the rulers of the khoshuns had to submit lists of candidates from whom a jiangjun approved a tusalakchy (Lipovtsev, 1828: 78-80). Minor officials received salaries, but only during the period of service in the administration office. For them, an official position became a source of wealth.

The arats, in turn, were divided into the relatively independent and the permanently dependent and the poor (Aranchyn, 1982: 3031). The arats-herdsmen, who had their own household, were major alban and unduruga payers ${ }^{10}$. The arats-herdsmen were attached to the khoshun and had no right to leave its territory without special permission of the ugerda. By its position, the first group of the arats is identical to the Mongolian estate of albatu. They had their own household, paid the alban and carried out various duties in favour of the noyon and the administration office. By the property position inside, the first group was differentiated by the number of cattle.

The second group of the arats that constituted the third class of the Tuvan society was less significant and had the following names: eshtenchi, kholechik, chalcha. Russian travellers and explorers who visited Tuva in the late $19^{\text {th }}-$ early $20^{\text {th }}$ centuries defined their position quite clearly. F.Ia. Kon writes: "When entering an aal you could notice a yurt that is larger and seemingly stronger than the others. This yurt belongs to a rich man, after whom the ulus was named. Near this yurt there are three or four yurts of the poor who used horses and cattle of the rich man when needed and who were shepherds of herds that belonged to the "bai kizhi" (the rich man) or his "edzhim" - "servant companions" (Kon, 1934: 165). Eshtenchiler, kholechik, chalcha were the people working for the wealthy Tuvinians whether they had their own yurts or not. The term "eshtenchileri" derives from the Tuvan word "esh" - a companion, friend, and, therefore, they were constant companions of the noyon, bai in a nomad camp. The eshtenchileri carried out various works: grazed cattle, pounded millet, collected firewood, etc. Finally, the last category is the impoverished arats. In the first decade of the $20^{\text {th }}$ century their number reached about 3 thousand, since wealthy families could not provide them with work.

\section{Conclusion}

Thus, having briefly described the social structure of the traditional Tuvan society, we can see a sharp property differentiation that, on the one hand, is the result of ethno-social processes and, on the other hand - a peculiarity of extensive nomadic cattle breeding, when the family well-being was entirely dependent on natural conditions exacerbated by the lasting effects of the Manchu domination. Legal officialdom that had a special social status 
was regulated by the Code of the Chinese Chamber of External Affairs (Lifan Yuan Zeli), as well as by the local customs and traditions. It is known that in Tuva such titles, ranks and positions as Bugude-darga (ambyn-noyon), ugerda (ruler of the khoshun), maeren, chalan, khundu were hereditary. The Tuvan officialdom that was formed in the difficult conditions of subordination to imperial China managed to find a way to keep its former social status - a line of tribal rulers of zaisans survived until the beginning of the last century. An official was a significant figure in the outskirts being not only a state policy guide, but also influencing culture, social behaviour and consciousness. The officialdom of Tuva was not only a representative of the Mongolian-Manchurian administration, but also was a centre of the local authorities that played a crucial role in the effective functioning of the state apparatus. At the end of the $19^{\text {th }}$ century a Tuvan official managed to acquire a new level of legitimacy of power combining the traditional dominance with the state privileges and honours as a representative of Bogdo-khan (Emperor) in Tuva. At the same time, an essential quality of the official was a mediatory function to ensure dialogue between the local community and the government. Despite the fact that the years of the Manchu domination had a negative impact on the socio-economic development of the Tuvan ethnos, at the turn of the century in Tuva there was a mixture of several cultures: the traditionally nomadic, the settled agricultural and the one with elements of the capitalist system. This contributed to the transformation of the social structure of the traditional nomadic civilization, which led to further changes in the political organization and culture of society.

\footnotetext{
$1 \quad$ Alban (Tuv.) or Alba (Mong.), literally - "a tribute, tax, in-kind duty", but in the official correspondence between departments this word was used to mean a "fur tax".

2 Amban (Manchu) - a title for persons appointed by the Beijing government to the highest public positions. In Khalkha, an Uliassutai Jiangjun and supreme rulers in the cities of Urge, Kobdo and Uliassutai were called Ambans. In these cities there were two Ambans - one from Manchuria, and the other from Mongolia and Noyon (Mong.). Noyon (Noyan, Noin) is an ancient Mongolian princely title meaning a sovereign prince. Ambyn-Noyon - a title of a supreme ruler in Tuva who governed the Tuvan khoshuns. The title of the Tuvan Ambyn-Noyon was inheritable.

3 Central administration of Tannu-Tuvan and Altai lands established since 1768 where the Jiangjun's residence was located. Jiangjun is a governor of the emperor in Northern Mongolia and Kobdo, where the "foreign order" was created.

4 Khoshun (Mong.) - a name of the administrative-territorial unit in Tuva; in Tuvan language it is "kozhuun" meaning a district. 5 Village chief.

6 The word "zaisan" derives from the Chinese title "Zai-xiang" - a head of a clan, governors of aimaks since the second half of the $15^{\text {th }}$ century.

7 Bugude-darga (Tuv.) - "Supreme Ruler". The institution of Bugude-darga was created in 1762 for the supreme control over the united Tuvan khoshuns (administrative units).

8 Also ogurta, ogurda, ukherida, ukher-da, ukher-daa. In the works of G.N. Potanin it is ukhyrda. Ugerda (Chinese Zongguan) - a ruler who enjoyed the rights of the dzasaks (Mong. - a ruler of the principality who did not received a princely rank, but enjoyed full authority in the territory under his jurisdiction); however the position was not considered hereditary, but elective - subject to approval by a jiangjun.

9 In Tuva lamas as a class occurred in the middle of the $18^{\text {th }}$ century due to the construction of Buddhist monasteries. The Manchus declared Buddhism as a state religion.

10 Undurug (Tuv.) - a duty levied by local rulers to support the administration.
}

\section{References}

Adrianov, E. V. (1886). Puteshestvie na Altai i za Saiany, sovershennoev 1881 godu [Journey to the Altai and Sayan committed in 1881]. Sankt-Petersburg, Tipografiia imperatorskogo geograficheskogo obshchestva, $276 \mathrm{p}$.

Afrikanov, A. M. (1890). Uriankhaiskii krai i ego obitateli [Uryankhai territory and its inhabitants] In Izvestiia vostöchno-sibirskogo otdela imperätorskogo rýsskogo geograficheskogo öbshchestva, 21(5), 34-59 p. 
Aranchin, Iu.A. (1982). Istoricheskii put' tuvinskogo naroda $k$ sotsializmu [The historical path of the Tuvan people to socialism], Novosibirsk, Nauka.sibirskoe otdelenie, 339 p.

Belov, E.A. (1999). Rossiia i Mongoliia (1911-1919 gg.) [Russia and Mongolia (1911-1919)], Moscow, Institut vostokovedeniia Rossiiskoi akademii nauk, 238 p.

Belov, E.A.(1997). Rossiia i Kitai v nachale XX v.: russko-kitaiskie protivorechiia v 1911-1915 gg. [Russia and China in the early XX century .: Russian-Chinese conflict in 1911-1915 years], Moscow, Institut vostokovedeniia Rossiiskoi akademii nauk, 314 p.

Bichurin, N.Ia.(1834). Istoricheskoe obozrenie oiratovili kalmykovs XV stoletiia do nastoiashchego vremeni [Historical review and oirat kalmyk with the XV century to the present time], Sankt-Petersburg, Tipografiia Meditsinskogo departamenta Ministerstva vnutrennikh del, 255 p.

Brunnert, I.S., Gagel'strom, V.V. (1910) Sovremennaya politicheskaya organizatsiya Kitaya [Modern political organization in China]. Pekin, Tipografiia Uspenskogo monastyria pri pusskoi duhovnoi missii, 1910. $380 \mathrm{p}$.

Chzhan, mu, Khe-tsiu-tao. (1895). Men-gu-iu-mu-tszi. Zapiski o Mongol'skikh kochev'iakh [Notes on the Mongolian nomad camps]. Per. s kit. P.S. Popova, st. dragomana i gen. konsula v Pekine, chl.-kor. Akad. nauk. Sankt-Petersburg, Skoropech. P.O. Iablonskogo, 598 p.

Datsyshen, V.G.(2005). Saianskii rubezh. Iuzhnaia chast' Prieniseiskogo kraia i russko-tuvinskie otnosheniia v 1616-1911 gg. [Sayan Border-Line. South Part of Near-Yenisei Region and Russia-Tuva Relations in 1616 - 1911], Tomsk, Scientific \& Technical Translations (STT), 247 p.

Datsyshen, V.G., Ondar, G.A. (2003). Saianskii uzel: Usinsko-Uriankhaiskii krai i russko-tuvinskie otnosheniia v 1911-1921 gg. [Sayan site: Usinsk-Uryankhai edge of and Russian-Tuvan relations in 1911-1921 years], Kyzyl, Respublikanskaia tipografiia, 278 p.

Dulov, V.I. (1956). Sotsial'no-ekonomicheskaia istoriia Tuvy (XIX-nachalo XXvv.) [The socio-economic history of Tuva (XIX-early XX centuries], Moscow, Izdatel'stvo Akademii nauk SSSR, 608 p.

Grumm-Grzhimailo, G.E. (1926) Zapadnaia Mongoliia i Uriankhaiskii Krai. Antropologicheskii $i$ etnograficheskii ocherk etikh stran [Western Mongolia and the Uriankhai Country. The anthropological and ethnographic sketch of these countries], Leningrad, Izdatel'stvo Gosudarstvennogo Russkogo geograficheskogo obshchestva, $413 \mathrm{p}$.

Grumm-Grzhimailo, G.E. (1930) Zapadnaia Mongoliia i Uriankhaiskii Krai. Antropologicheskii $i$ etnograficheskii ocherk etikh stran. Torgovlia i kolonial'naia deiatel'nost' kitaitsev i russkikh. Dopolneniia i popravki [Western Mongolia and the Uriankhai Country. The anthropological and ethnographic sketch of these countries. Trade and colonial activities of the Chinese and Russian. Additions and amendments], Leningrad, Izdatel'stvo Gosudarstvennogo Russkogo geograficheskogo obshchestva, $858 \mathrm{p}$.

Iakovlev, E.K. (1900). Etnograficheskii obzor inorodcheskogo naseleniia doliny Iuzhnogo Eniseia [Ethnographic review inorodcheskogo population of South Valley Yenisei], Minusinsk, Tipografiia V.I. Kornakova, 357 p.

Iezuitov, V. M. (1956). Ot Tuvy feodal'noi k Tuve sotsialisticheskoi [From Tuva Tuva feudal to socialist], Kyzyl, Tuvinskoe knizhnoe izdatel'stvo, 208 p.

Kabo, R.M. (1934). Ocherki istorii i ekonomiki Tuvy. Dorevoliutsionnaia Tuva. [Essays on the history and economy of Tuva. The prerevolutionary Tuva], Moscow, Leningrad, Gosudarstvennoe sotsial'no-ekonomicheskoe izdatel'stvo, 202 p. 
Kaiskii, M. (1926). Uriankhaiskii vopros [Uryankhai question] In Severnaia Aziia, 4, p. 16-25.

Khovalyg S.S.(2010). Tsentr ili periferiia? Sistema gosudarstvennogo upravleniia v Tuve v kontse XIX - nachale XX vv. [Center or periphery? The system of public administration in Tuva in the end of the 19th and early 20th centuries] In Vestnike rossiiskogo universiteta druzhby narodov. Seriia: istoriia Rossii, 3, p. 97-109.

Khovalyg, S.S. (2007). Mongush Buyan-Badyrgy (1894-1932): lichnost' v istorii [Mongush Buyan Badyrgy (1894-1932): the person in the history]. In Vestnik Evrazii [Journal of Eurasia], 2 (36), 4272.

Kon, F.Ya. (1934). Ekspeditsiya v Soiotiyu. Za pyat'desyat let. Sobranie sochinenii. [Expedition Soyots. For fifty years. Collected Works]. T. III. Moscow, Izdatel'stvo Vsesoyuznogo obshchestva politkatorzhan i ssyl'noposelentsev, $293 \mathrm{p}$.

Leonov, N. (1923). Uriankhaiskii krai do nachala XX stoletiia [Uryankhai edge of to the beginning of XX century] In Novyi Vostok, № 3, p. 405-419.

Lipovtsev, S.V. (1828). Ulozhenie Kitaiskoi palaty vneshnikh snoshenii. Per. s man'chzhur. [Legal Code of China Chamber of External Relations]. T. I. Sankt-Petersburg, Tipografiia izdatel'stva narodnogo prossveshcheniia, $317 \mathrm{p}$.

Mannai-ool, M.Kh. Tuvintsy: Proiskhozhdenie i formirovanie etnosa. [Tuva: The origin and formation of the ethnic group]. Novosibirsk, Nauka, 2004. $166 \mathrm{~s}$.

Mintslov, S.R. (1915). Sekretnoe poruchenie (puteshestvie v Uryankhai) [Secret mission (journey to Uriangkhai)]. Riga, Sibirskoe knizhnoe izdatel'stvo, 276 p.

Moskalenko, N.P. (2004). Osnovnye problemy etnopoliticheskoi istorii Tuvy v XX veke.[ Basic problems of ethnopolitical history of Tuva in the XX century], Moscow, Nauka, 222 p.

Natsov, S. (1927). Natsional'no-osvoboditel'noe dvizhenie tuvinskikh skotovodov [The national liberation movement of Tuvan herders] In Novyi Vostok, 19, p. 42-50.

Potanin, G.N. (1883). Ocherki Severo-Zapadnoi Mongolii [Essays on the North-Western Mongolia]. Sankt-Petersburg, Tipografiia V. Krishbauma, v d. Moskovskovskogo finansov na Dvortsovoi ploshchiadi, $372 \mathrm{p}$.

Potapov, L.P. (1969). Ocherki narodnogo byta tuvintsev [Essays on Tuvan folk life]. Moscow, Nauka, 401 p.

Potapov, L.P. (1969). Ocherki narodnogo byta tuvintsev [Tuvan a national life essays], Moscow, Nauka, 401 p.

Pozdneev, A.M. (1896). Mongoliia i mongoly. Rezul'taty poezdki v Mongoliiu, ispolnennoi v 1892 1893 gg. A. Pozdneevym [Mongolia, and mongolians. The results of the trip to Mongolia, performed in the 1892- 1893 biennium A. Pozdneev], Sankt-Petersburg, Rossiiskoe geograficheskoe obshchestvo, $697 \mathrm{p}$.

Pozdneev, A.M. (1896). Pyat' kitaiskikh pechatei [Five Chinese stamps], In Otdel'nyi ottisk iz Zapisok Vostochnogo Otdeleneniia Imperatorskogo Russkogo Arkheologicheskogo Obshchestva [In a separate branch of the print Notes Imperial Russian Archaeological Society]. T. IX. Sankt-Petersburg, Tipografiia imperatorskoi akadimii nauk, $290 \mathrm{p}$.

Seifulin, Kh.M. (1968). K istorii inostrannoi voennoi interventsii i grazhdanskoi voiny v Tuve (1918-1921 gg.) [On the history of foreign military intervention and civil war in Tuva (1918-1921]. Kyzyl, Tuvinskoe knizhnoe izdatel'stvo, 1201 p. 
Serdobov, N.A. (1971). Istoriia formirovaniia tuvinskoi natsii [The history of tuvan nation], Kyzyl, Tuvinskoe knizhnoe izdatel'stvo, 1971, 482 p.

Shostakovich, S. (1929). Politicheskii stroi i mezhdunarodno-pravovoe polozhenie Tannu-Tuvy v proshlom i nastoiashchem [Political system and international legal status of the Tannu-Tuva, past and present], Irkutsk, Izdanie Irkutskogo universiteta, $48 \mathrm{p}$.

Vainshtein, S.I. (1961). Tuvintsy-todzhintsy: Istoriko-etnograficheskie ocherki [Tozhu tuvans: historical and ethnographic essays], Moskva, Izdatel'stvo vostochnoi literatury, 218 p.

Vatin-Bystrianskii, V. A. (1913). Minusinskii krai v XVII veke. Etiud po Sibiri [Minusinsk region in the XVII century. Study in Siberia], Minusinsk, Tipografiia A.F. Metelkina, 218 p.

Vatin-Bystrianskii, V.A. (1915). Uriankhaiskii vopros $\mathrm{v}$ 80-kh godakh proshlogo stoletiia [Uryankhai question in the 80s of the last century] In Sibirskii student, 7-8, 85-103 p.

Vladimirtsov, B.Ia. (2002). Raboty po istorii i etnografii mongol'skikh narodov [The works on the history and ethnography of the Mongolian people's], Moscow, Vostochnaia literatura Rossiiskoi akademii nauk, $557 \mathrm{p}$.

\title{
Чиновники и чиновничество середины XIX - начала XX вв. в социальной структуре Танну-Тувы
}

С.С. Ховалыг

Тувинский государственный университет Россия, 667000, Республика Тьвва,

Кьзыл, ул. Ленина, 36

\begin{abstract}
В статье охарактеризована соииальная структура тувинского традиичонного общества на рубеже ХІХ - начала ХХ вв. Проанализированы исторические условия формирования разных сословий и особое место, занимаемое чиновничеством. Чиновничество Тувы как неотъемлемая часть традииионного тувинского общества и административной системы маньчжурской империи Цин в Центрально-Азиатском регионе формировалось и существовало на основе иеленаправленной правительственной политики в области государственного управления. Исследование формирования и развития чиновничества в иелом является новым направлением в историографии Тувы. Исследование темы даст возможность глубже раскрыть вопрос формирования и эволючии состава управленческих кадров и может оказаться весьма полезным в решении проблем реформирования системь управления на современном этапе, и в первую очередь в национальных республиках.
\end{abstract}

Ключевые слова: амбын-нойон, хошун, угерда, государственный аппарат, чиновник, государственное управление, табунан (эфу) императорский зять, историография, бугуде-дарга, сословие, соииальная структура.

Научная спещиальность: 07.00.02 - отечественная история. 